\title{
Hybridization between Quercus robur and $Q$. petraea in a mixed oak stand in Denmark
}

\author{
Jan JENSEN $^{1 *}$, Anders LARSEN ${ }^{1}$, Lene R. NIELSEN $^{1}$, Joan CotTRELl ${ }^{2}$ \\ ${ }^{1}$ Forest \& Landscape, Faculty of Biosciences, Copenhagen University, Hørsholm Kongevej 11, 2970 Hørsholm, Denmark \\ ${ }^{2}$ Forest Research, Northern Research Station, Roslin, Midlothian EH25 9SY, UK
}

Keywords:

Quercus robur /

Quercus petraea /

paternity analysis /

hybridization /

genetic diversity

(Received 29 September 2008; accepted 23 February 2009)

\author{
Mots-clés : \\ Quercus robur / \\ Quercus petraea / \\ analyse de paternité / \\ hybridation / \\ diversité génétique
}

\begin{abstract}
- Hybridization and mating pattern between Quercus robur and Q. petraea was studied in a 5.8 ha mixed forest stand in Jutland, Denmark which comprises in total 135 Quercus robur and 230 Q. petraea trees. Classification of the oak trees into species was performed using canonical discriminant analysis of a range of leaf morphological traits. Adult trees (365) and offspring (582) were genotyped with eight microsatellite markers. Seedlings were sampled in 2003 and acorns were collected in 2004. - Mating patterns of $Q$. robur and $Q$. petraea are expected to be different in the northern range of the distribution area and a larger hybridization rate is expected. It is further expected, that pollination from outside sources will be relatively less in small fragmented forest management systems compared to large scale oak forest. The conclusions should be verified through repeated year to year analysis of the mating pattern.

- Phenological studies revealed that there was no difference in flowering time between species. Data for the adult trees revealed no significant departures from Hardy-Weinberg proportions and there was weak, but significant spatial genetic structure, which supports the idea that the stand is of natural origin. Spatial genetic structure in the first distance class is stronger for $Q$. petraea. The genetic composition of the offspring was remarkably consistent from year to year. Paternity analysis revealed that, on average, $85 \%$ pollination came from fathers within the stand. The direction of the pollen flow varied from year to year. Inter-specific hybridization was high and ranged from 15-17\% and from 48$55 \%$ for $Q$. petraea and $Q$. robur mothers respectively. Paternity analysis revealed that the population was basically outcrossing and only $3.7 \%$ of the analysed progeny were the product of selfing. Over the two years of study, approximately 200 trees contributed to the paternity of the next generations. - The study confirms earlier studies with a greater tendency for $Q$. robur mothers to produce hybrid seeds than $Q$. petraea mothers. The rate of hybridization is higher in this Danish stand than in comparable studies elsewhere in Europe. Gene flow from outside sources are relatively low.
\end{abstract}

Résumé - Hybridation entre Quercus robur et $Q$. petraea dans un peuplement mélangé de chênes au Danemark.

- L'hybridation et le schéma de croisement entre Quercus robur et $Q$. petraea ont été étudiés dans une forêt mélangée de 5,8 ha dans le Jutland au Danemark. Cette forêt comprenait 135 arbres de Quercus robur et 230 de $Q$. petraea. Le classement des arbres dans les différentes espèces a été réalisé à partir de caractères morphologiques des feuilles grâce à une analyse canonique discriminante. Les arbres adultes (365) et leurs descendances ont été génotypés à l'aide de 8 marqueurs microsatellites. Les semis ont été échantillonnés en 2003 et les glands ont été récoltés en 2004.

- Le schéma de croisement entre $Q$. robur et $Q$. petraea est suspecté différent dans la partie nord de l'aire de distribution où un plus fort taux d'hybridation est également attendu. De plus, il est probable que la pollinisation à partir de pollen étranger soit plus faible dans des forêts fragmentées que dans des forêts continues de chênes. Des observations répétées d'année en année sont nécessaires pour valider ces hypothèses.

\footnotetext{
*Corresponding author: jsj@life.ku.dk
} 


\begin{abstract}
- Des études phénologiques montrent qu'il n'y a pas de différence entre les espèces pour la période de floraison. Les données sur arbres adultes ne révèlent aucun écart significatif par rapport aux proportions attendues de la loi de Hardy-Weinberg. Une structuration spatiale faible mais significative a été mise en évidence, qui suggère l'idée que le peuplement est d'origine naturelle. Cette structuration est plus forte pour $Q$. petraea. La composition génétique des descendances est remarquablement stable d'une année sur l'autre. Les analyses de paternité révèlent qu'en moyenne $85 \%$ de la pollinisation provient de pères du peuplement. Le sens de pollinisation varie d'une année sur l'autre. Le taux d'hybrides interspécifiques est élevé et varie de $15-17 \%$ et de $48-55 \%$ respectivement pour $Q$. petraea et $Q$. robur. Les études de paternité montrent que les inter-croisements sont la règle et que seulement $3,7 \%$ des descendants analysés sont issus d'autofécondation. Durant les deux années de l'étude, approximativement 200 arbres sont intervenus comme père pour les générations suivantes. - Cette étude confirme des études précédentes montrant que $Q$. robur produit plus de semences hybrides que $Q$. petraea. Le taux d'hybridation est plus élevé dans ce peuplement danois que dans d'autres études similaires en Europe. Les flux de gènes à partir de sources extérieures sont faibles.
\end{abstract}

\section{INTRODUCTION}

The genus Quercus comprises more than 500 species distributed across the northern hemisphere (Nixon, 1993). Species belonging to the same sub-genus are known to hybridize, and this has been the subject of much interest to biologists and foresters (e.g. Rushton, 1978; Bacilieri et al., 1995). However, despite many studies, the mechanism behind hybridization and speciation within the Quercus petraea $/ Q$. robur complex remains poorly understood. It has been debated whether the complex represents two distinct species or merely a hybrid swarm (Kleinschmit and Kleinschmit, 2000), or on the other hand the species are almost reproductively isolated from one another (Muir and Schlötterer, 2005). It has been further suggested that gene regulating mechanisms may control speciation (Scotti-Saintaigne et al., 2004). Indeed, the situation in Quercus has developed into a model with which to study ecology, genetics and evolution.

In northern Europe there is a general lack of experimental knowledge of mating patterns in the major native deciduous species, e.g. effective number of fathers, the existence of random mating and gene flow within and between stands. The unidirectional mating patterns between the two species have been demonstrated through controlled crosses (Steinhoff, 1998) and indirect assessment with markers (Bacielieri et al., 1995), but such studies need to be verified by direct studies of gene flow. The direct approach also offers the opportunity to study the year to year variation of the mating system.

Quercus robur L. and Q. petraea (Matt.) Liebl. represent the most frequent species belonging to the subgenus Quercus (White Oaks) which grow in the Northern European deciduous zone (Nixon, 1993). In the Nordic countries, both species can be found growing sympatrically as far north as Stockholm, which also represents the northern limit of $Q$. petraea. Quercus robur is a typical pioneer species while $Q$. petraea is regarded as a climax forest species. The two species share a large part of their distribution range and are known to coexist on many sites. They have been shown to hybridize to a variable but significant extent (Aas, 1993; Bacielieri et al., 1995; Steinhoff, 1998). However, despite direct evidence of hybridization, many of the mixed oak stands which have been studied in central Europe comprise two distinct morpholog- ical phenotypes, with little or no indication of intermediate forms (Kremer et al., 2002). Conversely, on the basis of intermediate morphology, it has been reported that hybrids might be common in Sweden (Johnson, 1952) and southern Norway (Jensen, unpublished data). A few Danish stands with putative hybrids have also been described by Gram et al. (1944).

One of the most successful approaches for classifying $Q$. robur and $Q$. petraea is based on multivariate analysis of a number of morphological traits (Rushton, 1978; Kremer et al., 2002). This has been used as a reference method for a number of extensive studies, including Kremer et al. (2002) on nine widely distributed European populations and Jensen et al. (2003) comprising eight Danish natural stands.

Various studies of $Q$. robur and $Q$. petraea based on a range of neutral biochemical and molecular markers show relatively low differentiation between species compared to other studies based on morphological markers and phenological/adaptive properties (Kremer et al., 1997; Scotti-Saintagne et al., 2004; Siegismund and Jensen, 2001; Jensen and Hansen, 2008). Although it has proven possible to identify markers which differ significantly in their allele frequencies between species at a local scale in Denmark (e.g. Siegismund and Jensen, 2001), recent studies with microsatellite and chloroplast DNA markers of pan-European samples have shown that $Q$. petraea and $Q$. robur to a large extent share the same alleles (Curtu et al., 2007). This is also why hybridization by pollen swamping from $Q$. petraea has been suggested as a key vector in gene flow which occurs following colonisation by $Q$. robur. In contrast, for $Q$. robur, long range seed dispersal is regarded as a key factor of gene flow (Petit et al., 2003). Spatial autocorrelation analysis also indicates different dispersal strategies for the two species (Lowe et al., 2004).

Microsatellite DNA markers have proved useful in the study of mating patterns of $Q$. robur and $Q$. petraea (Streiff et al., 1999; Buiteveld et al., 2001; Cottrell et al., 2003; Gugerli et al., 2007). These studies provide a snapshot of the reproductive mechanisms for a given site and are often performed for one season only. Nevertheless, despite these limitations, they have greatly contributed to our understanding of the various aspects of mating patterns e.g. specific combining abilities, selfing rates, effective number of fathers, effective population sizes (Lexer et al., 2000; Lowe et al., 2004). 
The aim of this study was to obtain estimates of hybridization between $Q$. robur and Q. petraea in Northern Europe and to compare the results with those from central Europe by investigating genetic structure, gene flow and reproductive processes in a fairly isolated, sympatric oak stand where both species coexist. According to the studies of Johnson (1952) a higher hybridization rate is expected in northern Europe.

This study is based on the use of detailed morphological and microsatellite data to discriminate the species of adult trees in the stand followed by paternity analysis of seeds and seedlings derived from these adult trees. The results of genetic structure and reproductive pattern including spatial structure and unidirectional mating systems are discussed in the context of earlier studies carried out in similar populations elsewhere in Denmark and other European countries.

Estimates of gene flow and pollination from sources beyond the stand have practical importance for breeding and conservation. Many studies of gene flow on oak are based on plots located within larger oak populations with high pollen flow rates e.g. the forest of Petite Charnie in France (Bacielieri et al., 1995). The oak stand of Velling in this study represents a small size forest stands in a typical silvicultural forest management system in deciduous temperate forest in northern Europe. Such small populations have often experienced fragmentation. The hypothesis is that gene flow from distant sources is expected to be restricted compared to larger continuous forest systems, as shown for common beech (Fagus sylvatica L.) (Jump and Peñuelas, 2006).

Observations of offspring from two years will provide more confident estimates of hybridization and gene flow parameters. It is possible that large differences may be observed due to possible differences in the phenological response of the species to the prevailing weather during successive seasons.

\section{MATERIALS AND METHODS}

\subsection{Study site}

The flora in approximately 400 natural oak stands in Western Jutland were botanically described by Gram et al. (1944). Mixed stands of $Q$. robur and $Q$. petraea are relatively rare in Denmark. Siegismund and Jensen's (2001) survey of genetic variation in 26 oak stands in Denmark revealed two mixed stands one of which, Velling forest, was selected for more detailed investigation in this project. The location of the stand coincides with the southern limit of the glaciers during the last glacial maximum 18000 B.C. The soil type gradually changes across the stand with a poor sandy soil in the west and a loamy soil to the east. The terrain is hilly with a $50-60 \mathrm{~m}$ height difference with a rising slope towards the north east. The stand is an intimate mixture of oak and beech forest which is surrounded by open space to the west and east, by conifer to the north and by beech forest to the south. A number of small, immature oak trees are found near the edge of the stand to the west, but otherwise, the nearest large oak trees are more than $200 \mathrm{~m}$ away to the south. The central core of the stand comprises $60 \%$ oaks and $40 \%$ beech, but the proportion of oak falls to $40 \%$ in the north-eastern part of the stand. Quercus petraea and $Q$. robur occur throughout the stand with no obvious pattern to their distribution (Fig. 1). The morphometric analysis described below shows that $Q$. petraea is twice as frequent as $Q$. robur.

The trees are estimated to be approximately 100 years old on the basis of their yield class and dimension, but major parts of the area are apparently old coppice forest, and the actual age of the genets must be considerably older. At least some parts of the forest have developed from coppice with standard management. No regular forest management is practised in the stand.

\subsection{Sampling}

The following characters were recorded for each oak tree in the stand; diameter at breast height (dbh), epicormic production and stem straightness. The trees vary in dbh between 30 and $80 \mathrm{~cm}$ and in height between 20 and $30 \mathrm{~m}$. The geographical coordinates for all oak trees in the stand were recorded with an accuracy of $+/-1 \mathrm{~m}$.

Five leaf samples were collected from the top of each mature tree in the stand. A standard protocol based on leaf morphology characters was used (Kremer et al., 2002). This included lamina length, petiole length, lobe width, sinus width, length of lamina from base to its largest width, number of lobes, number of intercalary veins, basal shape of the lamina and abaxial laminar pubescence.

Time of flushing and amount of male flowering were recorded for all trees in the stand in spring 2003 and 2004. The estimation of flushing was based on a continuous scale from 1 to 9 , where 1 is given to trees with no flushing, and 9 to trees with fully visible leaves. The estimation of male flowers was based on a continuous scale from 1 to 9 , where 1 is given to trees with no flowers, and 9 to trees with prolific flowering. Flowering and flushing were observed to occur more or less synchronously. It has only been possible to assess male flowering.

Samples for DNA isolation were collected from leaves or buds of all 365 mature oak trees in Velling forest. In addition, in 2003, leaf samples for DNA isolation were collected from 343 seedlings growing on the forest floor. Almost all of these represented seedlings which had germinated from acorns produced in 2002. Positions of seedlings were recorded using GIS. The seedlings were distributed directly beneath the canopy of 18 mother trees including representatives of both species. No seed was produced in 2003. In 2004, acorns were collected from directly beneath the canopy of 22 mother trees. The acorn crop was limited, and almost all the available seeds were collected. Seeds were produced by $10-15 \%$ of the trees in the central zone of the stand. The germination rate was poor $(12 \% Q$. robur and $19 \%$ Q. petraea) and only 239 plants could be investigated.

\subsection{Genotyping}

The Qiagen DNeasy plant mini kit was used for DNA isolation. All the DNA samples from mature trees, seedlings and germinated acorns were genotyped using eight microsatellite loci: MSQ4 and MSQ13 (Dow et al., 1995), AG9, AG104, AG30, AG96, AG11 and AG39 (Steinkellner et al., 1997). The first four were included in a previous study of oaks at Hald Ege in Denmark (Jensen et al., 2003). The PCR was initiated with $4 \mathrm{~min}$ at $94{ }^{\circ} \mathrm{C}$ followed by 35 cycles: $\left(30 \mathrm{~s}\right.$ at $94{ }^{\circ} \mathrm{C}, 1.5 \mathrm{~min}$ at $54{ }^{\circ} \mathrm{C}, 60 \mathrm{~s}$ at $72{ }^{\circ} \mathrm{C}$ ) ending with $20 \mathrm{~min}$ $60{ }^{\circ} \mathrm{C}$ (same conditions for all primers). PCRs were performed with the Qiagen PCR multiplexing mini kit, successfully scaled down to $8 \mu \mathrm{l}$ per sample. Fragments were analyzed on a Beckman $2000 \mathrm{xl}$ capillary sequencer by multiplexing microsatellite products in various four by four combinations. 


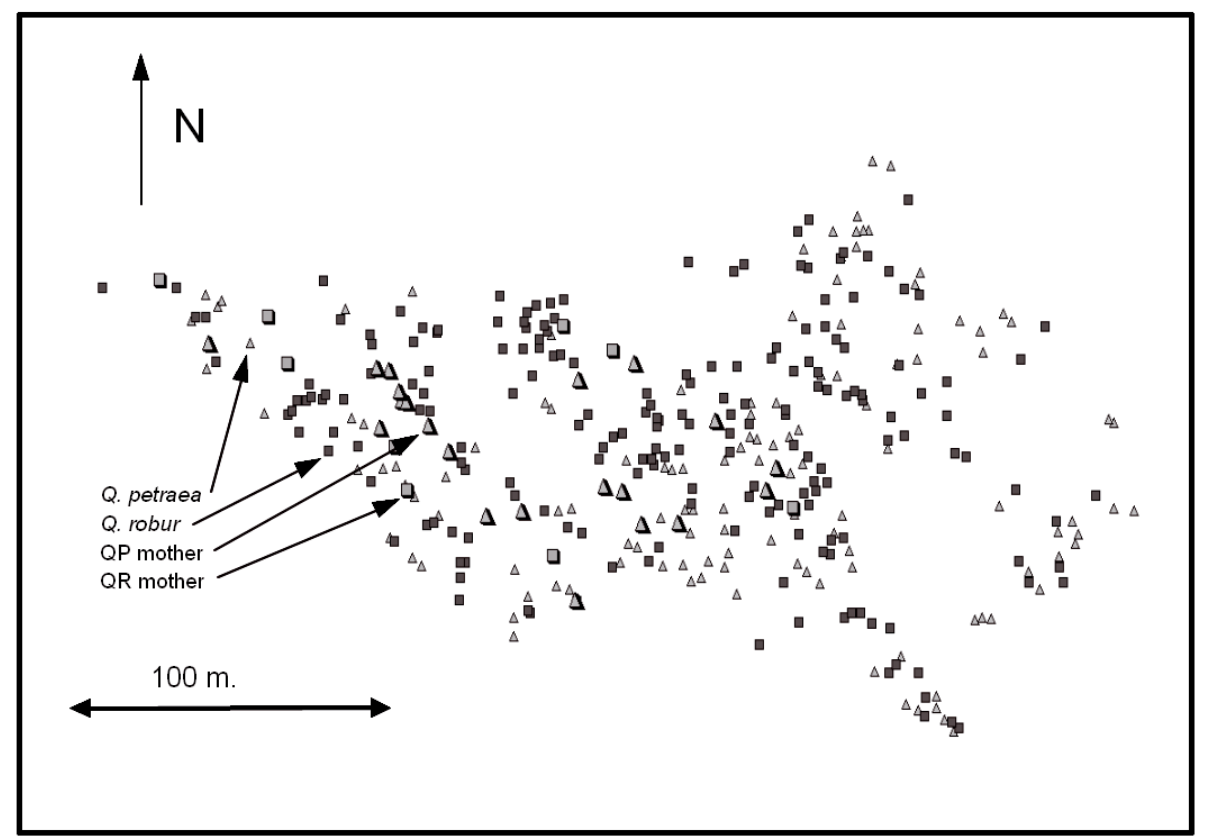

Figure 1. Diagram of the distribution of $Q$. petraea (small triangles) and $Q$. robur (small squares) adult trees in Velling forest. The location of the mother trees beneath which seed was collected is shown as large triangles for $Q$. petraea and large squares for $Q$. robur.

\subsection{Data analysis}

\subsubsection{Morphometric analysis}

Canonical discriminant analysis (CDA) was applied on a single tree basis (five leaves per tree) to the leaf morphology measurements. Canonical parameters were calculated for the nine non-weighted leaf characters according to Kremer et al. (2002). The robustness of the CDA analysis has been tested by Kremer et al. (2002). The original analysis, based on the measurements of leaves from seven Danish reference stands of $Q$. robur (60 trees) and $Q$. petraea (80 trees), was used for discrimination of species (Jensen et al., 2003). The multivariate procedures CANDISC and DISCRIM were applied to compare leaf characters and to classify canonical scores for the Velling stand using SAS (Anon., 1989).

\subsubsection{Molecular markers}

A few primers or loci showed nucleotide insertion, some of which have been reported by Mariette et al. (2000) and by Gugerli et al. (2007). In an attempt to reduce the number of miscalls which would lead to inaccuracies in paternity determination, alleles were grouped into two base pair bins using the method described by Mariette et al. (2000). The Genepop program version 4.0 (Raymond and Rousset, 1995) was used to calculate the following statistics to describe the microsatellite variation found in the adult trees of each species (after Brown and Weir, 1983): allelic richness $\left(A_{C}\right)$, observed heterozygosity $\left(H_{O}\right)$, expected heterozygosity $\left(H_{E}\right)$ and fixation index $\left(F_{I S}\right)$. Deviations of genotypic distributions from Hardy-Weinberg proportions were tested with Genepop version 3.4 (Raymond and Rousset, 1995). An unbiased estimate of the exact $P$-value of the test was obtained by using a Markov-chain algorithm with 10000 dememorization steps, 1000 batches and 10000 iterations per batch in each test. The sequential Bonferroni procedure was applied to calculate table-wide levels of significance (Holm, 1979). All tests per species were ranked according to their $P$-values. The test with the smallest $P$-value $\left(P_{1}\right)$ was declared significant on a "table-wide" significance level $\alpha$, if $P_{1}<\alpha / n$, where $n$ is the number of tests (here the number of loci). The second smallest $P$ value was judged significant if $P_{2}<\alpha /(n-1)$ and so on. $F_{S T}$ is estimated by a "weighted" analysis of variance (Weir and Cockerham, 1984), identifying $Q$. robur and $Q$. petraea as two populations. Due to the uneven sample size of $Q$. robur and $Q$. petraea the number of alleles per locus was evaluated after correcting for sample size with the programme HP-RARE 1.0 (Kalinowski, 2005). The sample size was kept at 135 (270 genes) per locus which was the number of $Q$. robur trees. At one locus (Ag30) the sample size was however 123 (246 genes) due to missing values.

In order to evaluate the structure of the parental generation at Velling, the molecular data from the adult trees were analysed using the model-based Bayesian clustering approach Structure 2.2 (Pritchard et al., 2000). The approach allows identification of individuals that are assigned jointly to two or more clusters and are thereby suggested to be hybrid candidates. The canonical discrimination of morphological characters was hereafter graphically compared with the Bayesian clustering analysis of microsatellite data to see whether the two methods produced the same clusters.

The spatial analysis of the adult trees was carried out using the programme SGS - Spatial Genetic software version 1.0c (Degen et al., 2001). This method was preferred here to more recent methods to enable direct comparison to be made with the results of Streiff et al. (1998) and Jensen et al. (2003). Correlogram plots of spatial genetic structure describe relatedness, here expressed as Moran's index, in relation to distance classes. The significant distance describes the maximum distance in meters when spatial autocorrelation is significant at the $95 \%$ level. Moran's index $I_{q}$ was used to examine spatial 
Table I. Selected morphologic and phenological characters for Velling forest for 230 trees of Q. petraea and 135 of $Q$. robur. Data from reference populations from Jensen et al. (2003).

\begin{tabular}{|c|c|c|c|c|c|c|c|c|c|c|c|}
\hline & $\begin{array}{l}\text { No. } \\
\text { of } \\
\text { indv. }\end{array}$ & $\begin{array}{l}\text { Petiole length } \\
\mathrm{mm}\end{array}$ & $\begin{array}{l}\text { No. of } \\
\text { venes }\end{array}$ & $\begin{array}{c}\text { Basal } \\
\text { shape } \\
1-9\end{array}$ & $\begin{array}{c}\text { Hairs } \\
1-6 \\
6=\text { many }\end{array}$ & $\begin{array}{l}\text { Acorn petiole } \\
\mathrm{mm}\end{array}$ & $\begin{array}{l}\text { Stem diameter } \\
\mathrm{cm}\end{array}$ & $\begin{array}{l}\text { Flushing } \\
2003 \\
1-9 \\
9=\text { far }\end{array}$ & $\begin{array}{l}\text { Flushing } \\
2004 \\
1-9 \\
9=\text { far }\end{array}$ & $\begin{array}{c}\text { Male flowering } \\
2003 \\
1-9 \\
9=\text { many }\end{array}$ & $\begin{array}{c}\text { Male flowering } \\
2004 \\
1-9 \\
9=\text { many }\end{array}$ \\
\hline Q. petraea & 230 & 13.7 & 1 & 5.3 & 3.9 & 7.8 & 42.9 & 6.75 & 2.91 & 6.30 & 5.60 \\
\hline Standard error & & 3.6 & 1.4 & 1.5 & 0.5 & 5.9 & 13.2 & 2.2 & 1.6 & 1.5 & 2.3 \\
\hline Q. robur & 135 & 6.2 & 2.4 & 7.1 & 2.4 & 28.5 & 44.6 & 6.35 & 3.32 & 6.80 & 6.15 \\
\hline Standard error & & 1.9 & 2.5 & 0.8 & 0.8 & 14.7 & 12.4 & 2.4 & 1.7 & 1.4 & 2.2 \\
\hline Reference Q.petraea & 80 & $14.8 \mathrm{~ns}$ & $0.9 \mathrm{~ns}$ & $3.9 \mathrm{~ns}$ & $4.6 *$ & & & & & & \\
\hline Reference Q.robur & 60 & $6.9 \mathrm{~ns}$ & $2.6 \mathrm{~ns}$ & $8.4 *$ & $2.2 \mathrm{~ns}$ & & & & & & \\
\hline
\end{tabular}

genetic structure (Cliff and Ord, 1973). Correlograms were computed using the methods described by Sokal and Wartenberg (1983), and correlations are performed over a range of distance classes $S_{q}$ :

$$
I_{q}=\frac{n \sum_{i=1}^{n} \sum_{j \neq i}^{n} w_{i j}\left(a_{i}-\bar{a}\right)\left(a_{j}-\bar{a}\right)}{W \sum_{i=1\left(a_{i}-\bar{a}\right)^{2}}^{n}} \quad W=\sum_{i=1}^{n} \sum_{j \neq i}^{n} w_{i j}
$$

where $n=$ total sample numbers, $w_{i j}=1$ if all ${ }_{i, j}$ belong to same distance class, otherwise $w_{i j}=0 . a_{i}=1$ if the $i$ th individual is homozygous for that allele, 0.5 if heterozygous and 0 if no copy of the allele is present; $\bar{a}=$ mean of a over all individuals. To test significant deviation from random spatial distribution of the estimated measures a permutation test based on Monte-Carlo simulations was applied (Manly, 2006). At each distance class, the observed values were compared with the distribution obtained after 5000 permutations.

\subsubsection{Paternity analysis}

Pollen flow and hybridization rate for the oak species were estimated by paternity analysis of the 582 offspring. The genotyping of the adult trees in the stand was performed twice to minimize genotyping errors. The paternity analysis was done using the CERVUS 3.0 program (Kalinowski et al., 2007). All offspring genotypes were compared to those of candidate fathers. If more than four out of eight loci of an offspring matched a candidate father, these samples were genotyped again, and this process was continued until every fatheroffspring relationship was verified. As $5 \%$ of the data are missing, the basic criteria for accepting fathers is that one allele per locus in at least 7 (out of 8) loci per offspring/father pair match. Furthermore, with eight loci, mismatching due to scoring errors becomes highly likely, see Kalinowsky et al., (2007). A relaxed significance of $80 \%$ was chosen, because Marshall et al. (1998) stated that paternities assigned with $80 \%$ confidence were more accurate than those obtained by the simple exclusion method. A sizeable component $(66 \%)$ of those offspring with identified fathers matched the candidate father at one allele per locus at all eight loci. The method is a modified total-exclusion paternity analysis (Robledo-Arnuncio and Gil, 2005; and Lowe et al., 2004, for review).

\section{RESULTS}

\subsection{Morphological data}

The first canonical score based on the leaf morphological characters listed in Table I showed a significant difference between the two species $(P<0.001)$. The second canonical

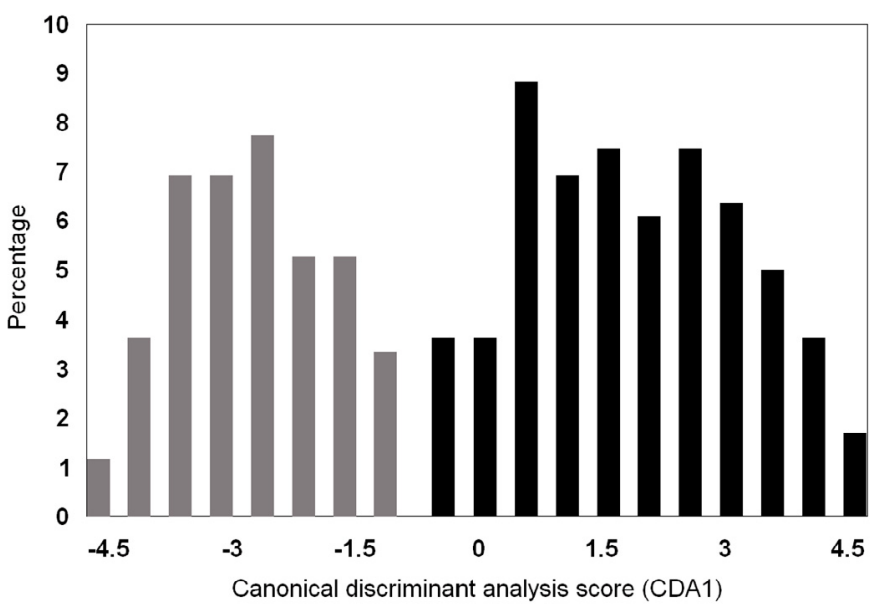

Figure 2. The frequency distribution of adult trees in Velling forest classified according to category of first canonical value based on analysis of a range of leaf parameters. Those trees to the left of canonical score -0.40 are identified as $Q$. robur and those to the right of -0.41 are classified as $Q$. petraea.

score based on the other leaf characters did not discriminate between the two species (data not shown). The distribution of the values of the first canonical variable produces a distinct bimodal distribution in which the two normal distribution curves intersect at CDA1 $=-0.40$ (Fig. 2). The tails of the two distributions are expected to overlap as discussed by Kremer et al. (2002). The two distribution curves are not equal, as there are fewer $Q$. robur than $Q$. petraea trees.

In many ways the two species were very similar. For example, the average dbh of $Q$. petraea was only slightly less $(43 \mathrm{~cm})$ than that for $Q$. robur $(45 \mathrm{~cm})$ and there was no significant difference in the range of flushing times between the two species in either 2003 or 2004. There was a strong correlation in flushing date for individual trees in 2003 and 2004 $(P<0.001)$ (data not shown). Furthermore, the two species did not differ significantly in the intensity of male flowering (total amplitude overlap) (Tab. I).

\subsection{Molecular markers}

Basic descriptive parameters for population genetic data are presented in Table II. The number of alleles per locus was in 
Table II. Nei's statistics at eight microsatellite loci for $Q$. robur and $Q$. petraea in Velling. allelic richness $\left(A_{C}\right)$, expected $\left(H_{E}\right)$ and observed heterozygosity $\left(H_{O}\right), F_{S T}$ and $F_{I S}$. Exclusion probabilities for one parent (Excl1), two parents (Excl2) and accumulated (Sum) two parents are shown.

\begin{tabular}{lcccccccccccccc}
\hline Allelic & Q. robur & Q petraea & \multicolumn{4}{c}{ Q. robur } & \multicolumn{4}{c}{ Q. petraea } & \multicolumn{4}{c}{ Both } \\
\cline { 2 - 14 } based & $A_{C}$ & $A_{C}$ & $H_{E}$ & $H_{O}$ & $F_{I S}$ & Prob. & $H_{E}$ & $H_{O}$ & $F_{I S}$ & Prob. & $F_{S T}$ & Excl(1) & Excl(2) & Sum \\
\hline AG30 & 30.0 & 23.3 & 0.83 & 0.78 & 0.061 & 0.11 & 0.73 & 0.74 & -0.002 & 0.06 & 0.047 & 0.41 & 0.60 & 1.000 \\
MSQ13 & 12.9 & 11.8 & 0.77 & 0.76 & 0.013 & 0.05 & 0.80 & 0.86 & -0.078 & 0.32 & 0.005 & 0.43 & 0.61 & 1.000 \\
AG96 & 17.7 & 16.7 & 0.66 & 0.69 & -0.048 & 0.55 & 0.83 & 0.83 & -0.007 & 0.12 & 0.090 & 0.45 & 0.63 & 0.999 \\
AG11 & 22.7 & 18.3 & 0.90 & 0.77 & 0.149 & 0.02 & 0.79 & 0.78 & 0.015 & 0.36 & 0.041 & 0.46 & 0.63 & 0.998 \\
AG9 & 12.7 & 11.3 & 0.86 & 0.81 & 0.047 & 0.08 & 0.83 & 0.90 & -0.079 & 0.0 & 0.005 & 0.47 & 0.65 & 0.996 \\
MSQ4 & 15.6 & 15.0 & 0.85 & 0.85 & -0.003 & 0.02 & 0.83 & 0.85 & -0.024 & 0.02 & 0.014 & 0.51 & 0.68 & 0.988 \\
AG39 & 26.3 & 22.8 & 0.90 & 0.87 & 0.035 & 0.13 & 0.89 & 0.87 & 0.026 & 0.05 & 0.013 & 0.55 & 0.71 & 0.962 \\
AG104 & 28.7 & 25.9 & 0.94 & 0.92 & 0.027 & 0.21 & 0.93 & 0.92 & 0.008 & 0.09 & 0.014 & 0.77 & 0.87 & \\
\hline Average & & & 0.84 & 0.81 & 0.039 & & 0.83 & 0.84 & -0.017 & & 0.029 & &
\end{tabular}

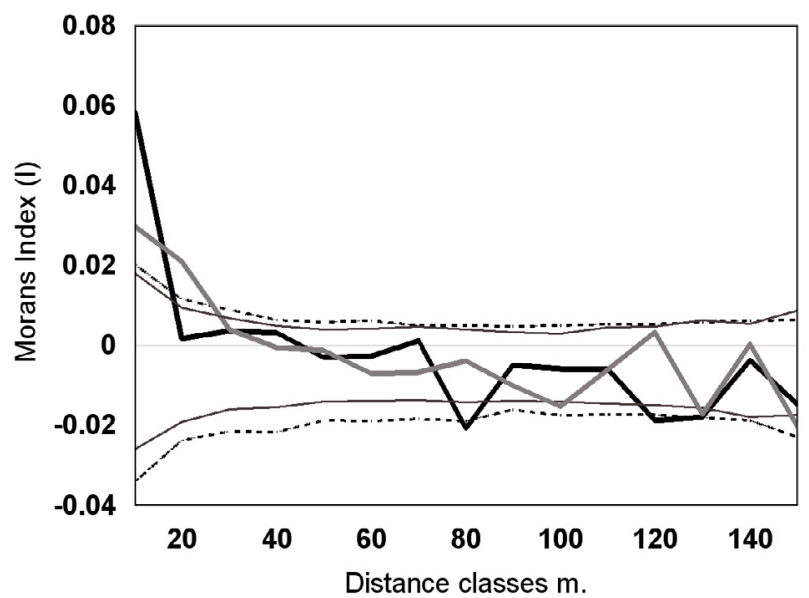

Figure 3. Spatial autocorrelation calculated by Morans Index among adult samples of $Q$. petraea (grey) and $Q$. robur (black). $95 \%$ confidence intervals based on 5000 permutations are presented as dotted black line for $Q$. robur and thin grey line for $Q$. petraea.

general higher in $Q$. robur than in $Q$. petraea also when corrected for sample size. The $F_{I S}$ values range between -0.05 to 0.15 for $Q$. robur and are lower for $Q$. petraea (between -0.08 and 0.03 ). In $Q$. robur two loci (MSQ4 and AG11) show small significant deviations from Hardy-Weinberg proportions. In $Q$. petraea, there was a significant excess of heterozygotes at one locus (AG9, $P<0.001$ ). However, when adjusted with the sequential Bonferroni technique for each species over all loci, only one of the deviations was significant at the 5\% tablewide level (Q. petraea, AG9). Otherwise, there were no significant departures from Hardy-Weinberg proportions. Comparisons between the two species show large differences in the frequencies of particular alleles within specific loci. For example, allele 237 at locus AG30, has a frequency of 0.23 for $Q$. robur but 0.48 for $Q$. petraea. Similar minor differences are observed for a few other alleles. There is no general indication of differences between species based on $F_{S T}$ scores.

A structure of relatedness exists in the adult oaks in the population (Fig. 3). There was a significant spatial autocor-

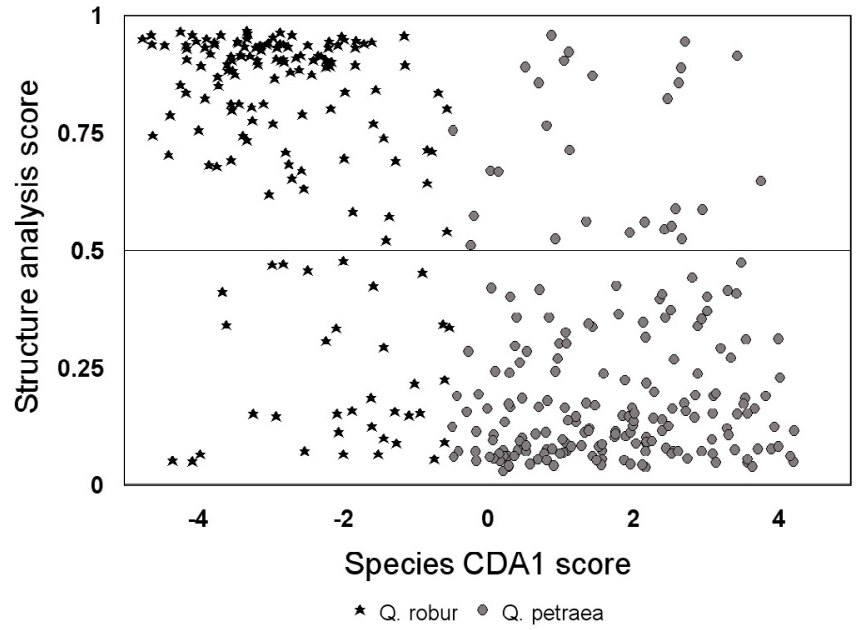

Figure 4. Relationship between canonical discriminant analysis (CDA1) based on leaf parameters and Structure analysis based on molecular data. The analysis includes all mature trees in the Velling forest.

relation up to $30 \mathrm{~m}$ for $Q$. petraea and over a shorter distance for $Q$. robur. There were no significant spatial patterns over the larger distances.

The set of microsatellites produced high exclusion probabilities calculated according to Jamieson (1994) (Tab. II). Two previous estimates of exclusion probabilities based on 6 microsatellite loci have been published by Valbuena-Carabana et al. (2005) (AG9, MSQ4, MSQ13) and Lepais et al. (2006) (AG11, AG39, AG96), both of which exhibited slightly higher exclusion probabilities than found in this study.

For the adult trees the relation between Morphological vector 1 (CDA1) of the canonical discriminant analysis and results from the Structure analysis of microsatellite data is shown in Figure 4. For the majority of samples there is a good correlation between the two vectors, but for both species there are $15-20 \%$ of individuals in which the classification based on morphological characters contradicts that based on the microsatellite vector. Some of the individuals which are classified 
Table III. Identification of mothers and fathers of offspring in the Velling forest in 2002 and 2004 based on microsatellite markers. When father genotype is equal to mother genotype, the offspring is the result of self-pollination (last column). Average female and male morphology scores (can1) are also given. The table is based on a segregation in two species groups (without estimating hybrids).

\begin{tabular}{|c|c|c|c|c|c|c|c|}
\hline & $\begin{array}{l}\text { \% Mothers } \\
\text { identified }\end{array}$ & $\begin{array}{c}\text { Number of } \\
\text { mothers }\end{array}$ & $\begin{array}{l}\text { Number of } \\
\text { offspring }\end{array}$ & $\begin{array}{l}\text { \% Fathers } \\
\text { identified }\end{array}$ & $\begin{array}{c}\text { Average score o } \\
\text { CDA1 }\end{array}$ & $\begin{array}{c}\text { Average score } \sigma^{\prime \prime} \\
\text { CDA1 }\end{array}$ & $\begin{array}{c}\% \\
\text { Selfings }\end{array}$ \\
\hline 2002 Q. robur & 0.89 & 5 & 38 & 0.79 & -2.57 & 0.22 & 2.6 \\
\hline 2002 Q. petraea & 0.89 & 13 & 224 & 0.87 & 1.67 & 1.08 & 4.5 \\
\hline 2004 Q. robur & 0.98 & 6 & 48 & 0.73 & -2.54 & -0.71 & 4.2 \\
\hline 2004 Q. petraea & 0.98 & 16 & 150 & 0.89 & 1.57 & 0.94 & 2.7 \\
\hline Total & & 40 & 460 & 0.82 & & & 3.7 \\
\hline
\end{tabular}

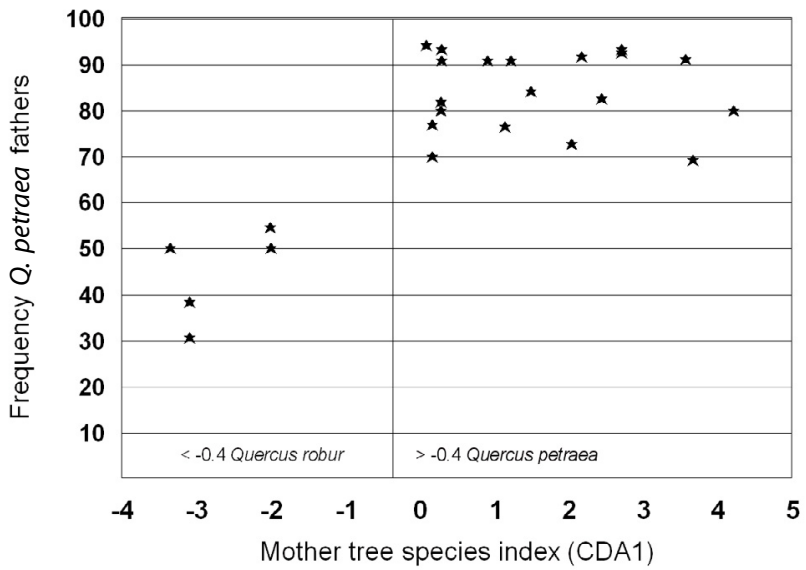

Figure 5. The frequency of pollination by $Q$. petraea fathers in the progeny arrays of mother trees of $Q$. robur and $Q$. petraea. The classification of mother trees is based on the Canonical Discriminant Analysis (CDA1) of a range of leaf parameters. The maternal arrays are only presented when the means are based on seven offspring or more.

on the basis of molecular data as $Q$. petraea have leaves which are characteristic of $Q$. robur and vice versa.

The 582 tested offspring were collected directly beneath the crown of seed bearing mother trees. Of these offspring, $89 \%$ in 2002 and $98 \%$ in 2004 had a genotype in which at least one allele per locus matched that of the mother tree that was directly above them when they were collected (Tab. III). When this was not the case, the individuals were discarded. The paternity analysis revealed that fathers (460 in total) could be identified in $73-79 \%$ and $87-89 \%$ of the offspring, i.e. the minimum pollination occurring from outside the stand is therefore estimated to be between $21-27 \%$ and $11-13 \%$ for $Q$. robur and $Q$. petraea respectively. Self pollination is on average $3.7 \%$ and is not linked to specific mother trees. The average canonical score for the leaf characters of individual mother trees ranged between -4.8 to 4.7 so that the sampled mother trees consist of representatives of the two species (Fig. 5). The morphological score of the fathers was used along with that of the mother to determine which seeds and seedlings were the product of a hybridization event.

Table IV summarizes the results of the paternity analysis for each mother tree. In total, over two years, $29 Q$. petraea, and only $11 Q$. robur mother trees contributed to the seed and seedling sample. The identified fathers are similarly divided into $Q$. petraea and $Q$. robur trees based on morphological characters. Using the information in Table IV, the relationship between the phenotype of the mother based on the CDA1 score of the morphological characters ( $x$ axis) and the proportion of $Q$. petraea in the total identified fathers for each mother is plotted in Figure 5. In order to base the figure on reliable means, only those mother trees with a minimum of seven offspring are shown. Figure 5 clearly demonstrates that the $Q$. petraea mother trees (19) preferentially mate with $Q$. petraea fathers so that on average $82 \%$ of the $Q$. petraea mothers mate with fathers of the same species. There is no relation between the morphological score of the mother tree and the rate of hybridization. In contrast, the five $Q$. robur mother trees produce offspring in which only approximately $55 \%$ of the fathers belong to the same species.

The rate of interspecific matings is relatively stable across the two sampling years (Tab. V). The hybridization rate is 14$17 \%$ in the offspring of female flowers of $Q$. petraea mothers compared to $48-57 \%$ when $Q$. robur acts as the mother (Fig. 5).

Many fathers contribute to pollination: a counting of paternal genotypes revealed that there were 140 fathers involved in 262 possible crosses with known mothers in 2002, and in 2004 the numbers were 120 fathers in 198 combinations. Across both seasons, a total of 199 trees were identified as fathers.

In a relatively few (5) instances, there is evidence of a specific combining effect between a mother and a father tree producing 5-7 full sibs. These seeds represent matings between close neighbours, which exhibited synchronous early flowering (data not shown).

The cumulative pollen flow distance curve varies between years and species (Fig. 6). The curves are leptokurtic (long tailed) and reveal long distance pollination. There is a relatively short pollination distance in $Q$. petraea mothers in both 2002 and 2004 and only $11-13 \%$ of the fathers are found outside the stand. The distances for $Q$. robur are far longer and $23-27 \%$ of fathers are from outside the stand. The two pollination curves representing the different sampling years of $Q$. petraea are almost identical.

A quantitative analysis of the position of fathers shows various patterns depending on the sampling year (Fig. 7). The distribution of the actual fathers does not reflect that of the potential fathers around the sampled mother trees. In particular, the 2004 data show that the majority of the pollen comes from 
Table IV. Table of matings listed for all offspring. The table provides for each mother; its morphological species score (CDA1), diameter at breast height (mothers), number of its offspring analysed with microsatellites, numbers of identified fathers contributing to its analysed offspring, percentage of these fathers classified as $Q$. robur and $Q$. petraea and average distance (m) between the mother and its identified pollinators (i.e. known fathers).

\begin{tabular}{|c|c|c|c|c|c|c|c|c|c|}
\hline Year & $\begin{array}{l}\text { Mother } \\
\text { ID }\end{array}$ & $\begin{array}{l}\text { CDA1 } \\
\text { score }\end{array}$ & $\begin{array}{l}\text { Mother } \\
\text { category }\end{array}$ & $\begin{array}{c}\mathrm{DBH} \\
\mathrm{cm}\end{array}$ & $\begin{array}{l}\text { Number } \\
\text { offspring }\end{array}$ & $\begin{array}{c}\text { Number of } \\
\text { fathers }\end{array}$ & $\begin{array}{c}\text { \% Q. petraea } \\
\text { fathers }\end{array}$ & $\begin{array}{c}\text { \% Q. robur } \\
\text { fathers }\end{array}$ & $\begin{array}{l}\text { Average distance } \\
\text { to father } \mathrm{m} .\end{array}$ \\
\hline 2002 & 32 & 4.22 & Q. petraea & 106 & 10 & 10 & 80 & 20 & 79.7 \\
\hline 2002 & 46 & 2.45 & Q. petraea & 67 & 23 & 19 & 83 & 17 & 64.4 \\
\hline 2002 & 82 & 3.58 & Q. petraea & 47 & 37 & 26 & 91 & 9 & 64.6 \\
\hline 2002 & 85 & 2.71 & Q. petraea & 56 & 27 & 25 & 93 & 7 & 56.7 \\
\hline 2002 & 87 & 0.29 & Q. petraea & 55 & 10 & 10 & 80 & 20 & 45.8 \\
\hline 2002 & 93 & 0.91 & Q. petraea & 55 & 22 & 17 & 91 & 9 & 57.1 \\
\hline 2002 & 106 & 2.40 & Q. petraea & 49 & 7 & 7 & 100 & 0 & 26.2 \\
\hline 2002 & 107 & 0.09 & Q. petraea & 55 & 17 & 12 & 94 & 6 & 40.6 \\
\hline 2002 & 108 & 0.30 & Q. petraea & 52 & 11 & 10 & 91 & 9 & 30.9 \\
\hline 2002 & 110 & 2.02 & Q. petraea & 64 & 1 & 1 & 100 & 0 & 11.2 \\
\hline 2002 & 179 & 0.18 & Q. petraea & 46 & 21 & 17 & 70 & 30 & 57.3 \\
\hline 2002 & 218 & 1.15 & Q. petraea & 31 & 17 & 15 & 76 & 24 & 51.7 \\
\hline 2002 & 422 & 1.50 & Q. petraea & 62 & 21 & 11 & 84 & 16 & 46.7 \\
\hline 2002 & 26 & -3.30 & Q. robur & 38 & 3 & 2 & 100 & 0 & 46.0 \\
\hline 2002 & 30 & -1.98 & Q. robur & 40 & 1 & 1 & 100 & 0 & 28.2 \\
\hline 2002 & 99 & -3.08 & Q. robur & 52 & 12 & 10 & 38 & 62 & 72.7 \\
\hline 2002 & 148 & -2.51 & Q. robur & 54 & 8 & 8 & 75 & 25 & 46.6 \\
\hline 2002 & 187 & -1.99 & Q. robur & 44 & 14 & 14 & 50 & 50 & 78.9 \\
\hline 2004 & 17 & 1.23 & Q. petraea & 50 & 11 & 6 & 91 & 9 & 30.2 \\
\hline 2004 & 46 & 2.45 & Q. petraea & 67 & 7 & 3 & 100 & 0 & 31.5 \\
\hline 2004 & 57 & 1.97 & Q. petraea & 54 & 6 & 5 & 100 & 0 & 103.3 \\
\hline 2004 & 75 & 1.01 & Q. petraea & 55 & 7 & 7 & 86 & 14 & 35.2 \\
\hline 2004 & 77 & 2.05 & Q. petraea & 48 & 11 & 11 & 73 & 27 & 82.2 \\
\hline 2004 & 78 & 0.82 & Q. petraea & 41 & 7 & 7 & 57 & 43 & 98.8 \\
\hline 2004 & 85 & 2.71 & Q. petraea & 56 & 15 & 11 & 93 & 7 & 34.8 \\
\hline 2004 & 87 & 0.29 & Q. petraea & 55 & 11 & 11 & 82 & 18 & 64.7 \\
\hline 2004 & 108 & 0.30 & Q. petraea & 52 & 2 & 2 & 100 & 0 & 80.1 \\
\hline 2004 & 147 & 1.39 & Q. petraea & 47 & 6 & 5 & 83 & 17 & 46.4 \\
\hline 2004 & 179 & 0.18 & Q. petraea & 46 & 13 & 12 & 77 & 23 & 56.4 \\
\hline 2004 & 180 & 3.68 & Q. petraea & 52 & 12 & 10 & 69 & 31 & 42.3 \\
\hline 2004 & 218 & 1.15 & Q. petraea & 31 & 8 & 8 & 50 & 50 & 56.4 \\
\hline 2004 & 225 & 2.18 & Q. petraea & 40 & 11 & 11 & 92 & 8 & 50.7 \\
\hline 2004 & 414 & 3.58 & $Q$ petraea & 62 & 8 & 8 & 100 & 0 & 46.3 \\
\hline 2004 & 415 & 0.30 & Q. petraea & 113 & 15 & 14 & 93 & 7 & 62.8 \\
\hline 2004 & 191 & -1.97 & Q. robur & 55 & 11 & 11 & 55 & 45 & 74.6 \\
\hline 2004 & 30 & -1.98 & Q. robur & 40 & 7 & 7 & 57 & 43 & 103.2 \\
\hline 2004 & 53 & -2.06 & Q. robur & 57 & 3 & 3 & 33 & 67 & 89.4 \\
\hline 2004 & 65 & -2.81 & Q. robur & 50 & 4 & 4 & 75 & 25 & 43.3 \\
\hline 2004 & 99 & -3.08 & Q. robur & 52 & 13 & 9 & 31 & 69 & 41.3 \\
\hline \multirow[t]{2}{*}{2004} & 501 & -3.35 & Q. robur & 44 & 10 & 9 & 50 & 50 & 84.5 \\
\hline & & 0.47 & & & 460 & 389 & 79 & 21 & 57.0 \\
\hline
\end{tabular}

fathers situated to the west of the mother trees whereas the majority of potential donors are located to the east.

\section{DISCUSSION}

\subsection{Species discrimination}

As done in a larger but similar survey (Kremer et al., 2002) and a previous Danish analysis (Jensen et al., 2003), it is possible to classify the oak trees into two groups on the basis of a multivariate analysis of selected leaf parameters. The analysis produced a bimodal distribution for the trees at Velling with overlapping distribution. This means that the classification of species in Velling is not unambiguous. The degree of overlap of the distribution curves differ clearly from the Danish reference populations (Jensen et al., 2003) and from four mixed forest in Europe: Petit Charnie in France, Büren in Switzerland, Sigmundherberg in Austria and Salinasco Mendia in Spain which all showed two discrete normal distributions and two distinct species (Kremer et al., 2002). 
Table V. Paternity analysis for Velling forest for acorns produced in 2002 (collected as seedlings in 2003) and acorns collected in 2004. CDA1 is average canonical discriminant leaf score of father and mother.

\begin{tabular}{lccccccccc}
\hline & & \multicolumn{3}{c}{2002} & & \multicolumn{3}{c}{2004} \\
\cline { 3 - 5 } \cline { 7 - 9 } Mother & Father & No & CDA1 & Freq \% & & No & CDA1 & Freq \% \\
\hline Q. petraea & Q. petraea & 190 & 1.79 & 85 & & 125 & 1.6 & 83 \\
Q. petraea & $Q$. robur & 34 & -2.48 & 15 & & 25 & 2.56 & 17 \\
Q. robur & Q. robur & 17 & -2.56 & 45 & & 25 & -3.07 & 52 \\
Q. robur & $Q$. petraea & 21 & 1.45 & 55 & & 23 & 1.45 & 48 \\
& & 262 & & & & 198 & & \\
\hline
\end{tabular}

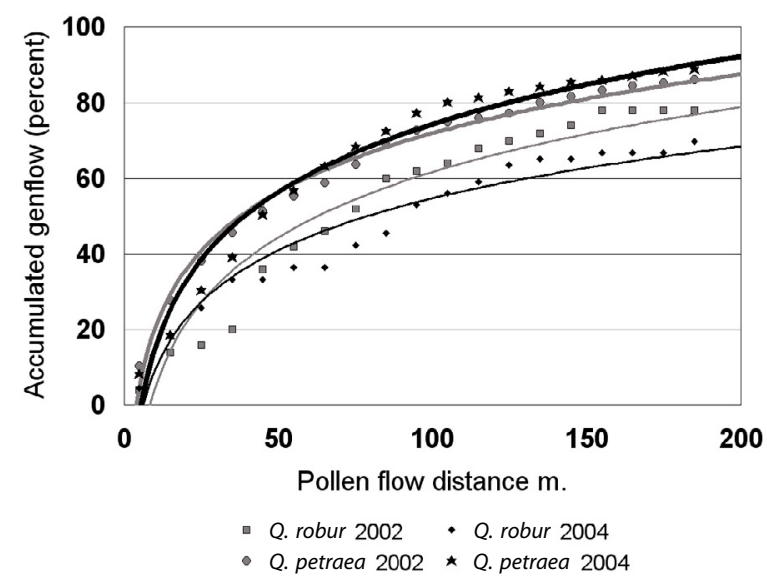

Figure 6. Cumulative pollination curves for the frequency of intermate distances in $Q$. robur and $Q$. petraea mother trees over two seasons. The points have been splined using a logarithmic function.

The Structure analysis of the microsatellite data from the adult trees also fails to divide all the samples into two clearly separate groups. In a similar study of a Romanian site in which the natural oak species coexist, Curtu et al. (2007) demonstrated a more distinct differentiation between $Q$. robur and Q. petraea. The study of Curtu et al. (2007), included the same microsatellites as applied in this study.

Our study revealed that there are individual trees, which are clearly assigned to $Q$. petraea in the molecular analysis (i.e. assignment values $>0.90$ ) but were morphometric ideotypes of $Q$. robur (and vice versa). One explanation for this lack of agreement between molecular and morphological analyses may lie in the presence of hybrids and backcrossed adult trees in the Velling stand. The physical appearance of hybrids in mixed stands of $Q$. robur and $Q$. petraea is discussed by Kremer et al. (2002). They point out, that although the morphological characters of a hybrid group might be expected to form a modality peak, their data for mixed stands, which are likely to contain a proportion of hybrids, show no such peak. They suggest that this could be because the introgressed and hybridized individuals resemble either $Q$. robur and/or Q. petraea so that no morphological intermediates are present. This means that within species variation will include "first or later generation hybrid" forms (maybe partly caused by ma-

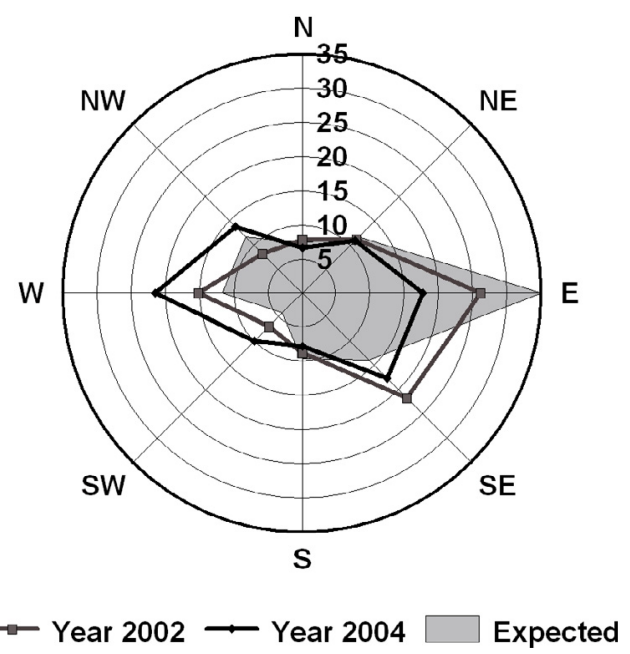

Figure 7. Circular histogram showing the expected and observed distribution of pollination events according to direction of pollen flow averaged over the progeny arrays of all sampled mother trees in Velling forest in years 2002 and 2004. The diagram shows the relative distribution in percent. The 'expected' category reflects the averaged frequency distribution of potential fathers around the sampled mother trees.

ternal effects). This could explain the morphometric variation in modality in Velling forest and possible superimposition of mainly the $Q$. petraea distribution group, which may comprise both pure and hybrid forms of the species. Specific F1 hybrids are difficult to identify, and one must assume that various types of interspecific backcrosses and hybrids exist. Following this logic, it would not be possible to differentiate between the pure species and the hybrid and back-crossed individuals.

\subsection{Molecular data}

The microsatellite analysis at Velling is more detailed than that performed earlier on samples from Hald Ege (Jensen et al., 2003). The exclusion probabilities for the microsatellites are high and theoretically 4-6 loci are fully adequate to determine parentage (Valbuena-Carabana et al., 2005; Dow and Ashley, 1996). Taking into account the high exclusion probabilities, the nature of a relatively isolated stand and the high frequency of fathers found, cryptic gene flow in this study was assumed to be low and was therefore not calculated.

\subsection{Spatial structure}

The results of spatial autocorrelation are similar to those obtained from Petite Charnie (Streiff et al., 1998) and for Q. petraea, are similar to another Danish oak stand at Hald Ege (Jensen et al., 2003). A close look at the parentage analysis confirms this spatial pattern, as many identified fathers are often adjacent trees, and possibly siblings. Therefore, it seems reasonable to assume that this is a natural stand. This confirms 
the information gathered from local farmers, indicating that the forest was once a harvested coppice area.

Spatial autocorrelation is significantly different from zero over a longer distance for $Q$. petraea than for $Q$. robur, which is similar to the result from Petite Charnie (Streiff et al., 1998). Strong spatial genetic structure over much longer significant distances of up to $160 \mathrm{~m}$ was found in two forests in northern England and Scotland. Again, the longest significant distances were found in $Q$. petraea (Cottrell et al., 2003). The relatively short "significant distances" in closed forest types such as Velling and Petite Charnie compared to open type of northern English and Scottish stands may be explained by the relatively short distance movement of acorns in these stands. Cottrell et al. (2003) further suggest that the difference between $Q$. petraea and $Q$. robur might partly be caused by a fitness advantage of $Q$. petraea caused by its superior ability to regenerate within a closed forest. The higher fitness of relatively shade tolerant $Q$. petraea seedlings should enable them to out-compete other species, and thereby maintain spatial structure over longer distances (Petit et al., 2003). Another proposed reason for the different structure exhibited by the two species is the preference of dispersal vectors such as jays based on acorn morphology (Bossema, 1979).

\subsection{Hybridization}

The present study reveals significant levels of hybridization (15-55\%) at Velling, which are higher than in similar studies in central Europe (e.g. Aas, 1993; Steinhoff, 1998; Streiff et al., 1999). The hybridization is, to a large extent, unidirectional with particular frequent pollination of $Q$. robur mothers by $Q$. petraea fathers.

The hybridization estimates might be biased if the potential fathers to a large extent are hybrids or backcrosses. To test this, the analysis was repeated omitting morphological parents with canonical score between -1.4 and 0.6 (compare with Fig. 2). A total of 130 offspring were omitted. The hybridization rate was not changed, which supports the theory of hybridization between morphological ideotypes (data not shown).

The rates of pollination and hybridization for both species are consistent between years (2002 and 2004). However, it should be noted that $Q$. petraea trees greatly outnumber $Q$. robur in the stand and this may favour the higher rate of hybridization of $Q$. robur mothers so that this type of hybridization may be less frequent in woods in which the frequency of the two species is more equal.

These results of greater hybridization in $Q$. robur mothers confirm those of several earlier studies. For example, Aas (1993) Steinhoff (1998) reported that in controlled crosses, hybridization is more likely to occur when $Q$. robur acts as the female parent. The same was true of natural, in situ gene flow in the Petite Charnie oak forest (Bacilieri et al., 1996; Streiff et al., 1999).

Backcrossing from hybrids could also be a significant vector in the gene exchange between species as such matings could occur more readily than hybridization between pure species. This has been tested and discussed by Olrik and Kjær (2007).

As the hybridization rate in Velling is significant and relatively unidirectional, it might be expected eventually to lead to one, unimodally distributed gene pool (by stabilising selection). Empirical experience shows the existence of many stands in central Europe which contain both $Q$. robur and Q. petraea (Kremer et al., 2002), and for these species to remain distinct despite ongoing hybridization, it is necessary to invoke a role for strong disruptive selection forces. Besides prezygotic selection, selection on various traits is likely to occur at the postzygotic stage, in particular soon after germination, as seedlings of $Q$. petraea and $Q$. robur have strong ecogeographical preferences (Parelle et al., 2007). In practice, this can diminish the effect of hybridization. Dering and Lewandowski (2007) have demonstrated that species structure can be dramatically altered between $Q$. robur and $Q$. petraea depending on fitness and postzygotic selection of seeds and plants. Tendency towards closed forest canopy will promote survival of $Q$. petraea seedlings whereas large open forest gaps will promote the survival of $Q$. robur seedlings.

Despite the observation that Velling forest exhibits a high rate of hybridization and the occurrence of many intermediate morphological types, botanical surveys have not found many putative intermediate or mixed oak stands elsewhere in Denmark (Gram et al., 1944). This also indicates that postzygotic selection and fitness is likely to have a significant role in determining the species composition of natural Danish oak stands.

Even if hybrid-containing stands of these species are more common towards the north of the distribution area (see Kremer et al., 2002, for review), the reason for this is poorly understood. Flowering in Velling is fully synchronized between the two species. Lowe et al. (2004) suggest that greater synchrony of flowering in Scandinavia may explain why hybridization has been observed to happen more frequently in these more northern latitudes (Johnson, 1952). However, the fact that synchrony has also been observed much further south in the French forest of Petite Charnie (Bacilieri et al., 1995) does not support this theory.

\subsection{Pollination from outside the stand}

The proportion of pollination by fathers from outside the stand is much smaller than in previous studies for similar sized stands (e.g. Streiff et al., 2002) and this is probably due to the greater isolation of the Velling stand. There are many young oaks around the stand, but the closest large oaks are positioned more than 200-300 m away.

The nature of long distance pollination and leptokurtic pollen distribution curves in this study do not deviate markedly from those produced by other studies of wind-pollinated species, see Burczyk et al. (2004) for a review. There was no significant difference in pollination distance, between 2002 and 2004 for Q. petraea.

In this study, a minimum of $11-27 \%$ of the pollen originates from outside the stand with a greater proportion of the Q. robur mothers receiving this distant pollen. This may partly 
be explained by the presence of fewer trees of $Q$. robur in the stand and by sampling error because it was only possible to collect under a limited number of $Q$. robur mother trees. It can also be explained by a larger influx of pollen from outside sources of $Q$. robur, however it has not been possible to verify this.

As the population is relatively isolated from large, pollen bearing oak trees (at least 200-300 m), it can be assumed that a large part of the distant pollination originates from trees growing more than this distance away. The small size of oak pollen grains increases the likelihood of the pollen being transferred over these long distances (Ducousso et al., 1993).

There will presumably be significant variation in the contribution of pollen from beyond the stand between years. Both the intensity of male flower production and the direction of the prevailing wind differ between years. It was expected that prevailing wind conditions could favour pollination direction and this hypothesis is supported by this study as there are differences in pollination directions between years. It has not been possible to obtain wind data for the period.

\subsection{Implications for breeding of oak}

Many countries have breeding programmes for oaks which are based on the testing of half-sib progenies (Jensen, 2000). For this approach it is important that the acorns collected are the true progeny of identified mother trees, and that assortative mating has occurred in the stand (Jensen et al., 1997). In this study, around $89-98 \%$ of the acorns were confirmed to be the true offspring of the identified mothers they were collected beneath. This demonstrates that the vast majority of acorns do not move far in a closed forest situation. The large percentage (98\%) of seedlings collected in 2004 belonging to the expected mother is however biased by the fact that only a few trees produced acorns that year, and by the efforts which were made to select acorns with the same shape and colour to optimize the likelihood that acorns came from the same mother. Nevertheless, the results show that, in most cases, the maternity of acorns gathered from beneath specific trees can be assigned with sufficiently high accuracy.

The results also confirm that a large number of fathers are implicated in siring offspring (however a few early flowering individuals had strong assortative mating). In single species, even-aged populations this will lead to a status of random mating over years.

Acknowledgements: This project was financed by the European Commission. FP 5, QLK5-1999-30960 OAKFLOW. We thank Lena Byrgesen, Viggo Jensen, Mogens Krog, Ditte Olrik, Lars Nørgaard Hansen and Thomas Kun $\varnothing$ for technical assistance in the field and in the laboratory. We also thank two anonymous reviewers for helpful comments on an early version of the manuscript.

\section{REFERENCES}

Anon., 1989. SAS/STAT User's Guide Version 6. 4th edition, 2 vol. SAS Institute Inc., Cary, North Carolina. 1848 p.
Aas G., 1993. Taxonomical impact of morphological variation in Quercus robur and $Q$. petraea: a contribution to the hybrid controversy. Ann. Sci. For. 50: 107-113.

Bacilieri R., Ducousso A.. Petit R., and Kremer, A., 1996. Mating system and assymmetric hybridisation in a mixed stand of European oaks. Evol. 50: 900-908.

Bacilieri R., Ducousso A., and Kremer A., 1995. Genetic, morphological, ecological and phenological differentiation between Quercus petraea (Matt.) Liebl. and Quercus robur L. in a mixed stand of Northwest of France. Silvae. Genet. 44: 1-10.

Bossema I., 1979. Jays and oaks: an eco-ethological study of a symbiosis. Behaviour, 70: 1-117.

Brown A.H.D. and Weir B.S., 1983. Measuring genetic variability in plant populations. Isozymes in plant genetics and breeding. In: Tanksley, S. D. and Orton, T. J. (Eds.), Developments in plant genetics and breeding. Part A: 219-239. Elsevier Science Publishers BV, Amsterdam. No. 1. Netherlands.

Burczyk J., DiFazio, S.P., and Adams W.T., 2004. Gene flow in forest trees: How far do genes really travel? For. Genet. 11: 179-192.

Buiteveld J., Bakker, E.G. Bovenschen J., and de Vries, S.M.G., 2001. Paternity analysis in a seed orchard of Quercus robur L. and estimation of the amount of background pollination using microsatellite markers. For. Genet. 8: 331-337.

Cliff A.D. and Ord J.K., 1973. Spatial Autocorrelation. Monographs in Spatial and Environmental Systems Analysis, No. 5. London, Pion ltd. $178 \mathrm{p}$.

Cottrell J.E., Munro R.C., Tabbener H.E., Milner A.D., Forrest G.I., and Lowe A., 2002. Comparisons of fine scale genetic structure within two British oakwoods using microsatellites; impacts of recolonisation dynamics and past management. For. Ecol. Manage. 176: 287-303.

Curtu A., Gailing, O., and Finkeldey R., 2007. Evidence for hybridization and introgression within a species-rich oak (Quercus spp.) community. BMC Evol. Biol. 7: 218 doi:10.1 186/1471-2148-7-218. 15 p.

Degen B., Petit R., and Kremer A., 2001. SGS - Spatial Genetic Software: A computer program for analysis of spatial genetic and phenotypic structures of individuals and populations. J. Hered. 92: 447-448.

Dering A., and Lewandowski A., 2007 Unexpected disproportion observed in species composition between oak mixed stands and their progeny populations Ann. For. Sci. 67: 413-418.

Dow B.D., Ashley M.V., and H.F. Howe., 1995. Isolation and characterization of highly variable (GA/CT)n microsatellites in the bur oak, Quercus macrocarpa. Theor. Appl. Genet. 91:137-141.

Dow B.D. and Ashley M.V., 1996. Microsatellite analysis of seed dispersal and parentage of saplings in bur oak, Quercus macrocarpa. Mol. Ecol. 5: 615-627.

Ducousso A., Michaud H., and Lumaret R., 1993. Reproduction and gene flow in the genus Quercus L. Ann. Sci. For. 50 (Suppl.): 91s-106s.

Gram K., Jørgensen, C.A., and Köie M., 1944. De jydske egekrat og deres Flora, Det Kgl. Danske Videnskabernes Selskabs Biologiske Skrift. Bd. III, Nr. 3. København (in Danish).

Gugerli F., Walser J.-C., Dounavi K., Holderegger, R., and Finkeldey, R., 2007. Coincidence of small-scale spatial discontinuities in leaf morphology and nuclear microsatellite variation of Quercus petraea and Q. robur in a mixed forest. Ann. Bot. 99: 713-722.

Holm S., 1979. A simple sequentially rejective multiple test procedure. Scand. J. Stat. 6: 65-70.

Jamieson A., 1994. The effectiveness of using co-dominant polymorphic allelic series for (1) checking pedigrees and (2) distinguishing fullsib pair members. Anim. Genet. 25: 37-44.

Jensen J.S., Olrik, D.C., Roulund H., and Lowe, A., 2003. Population genetics and spatial autocorrelation in an unmanaged stand of Quercus petraea in Denmark. Scand. J. For. Res. 18: 295-304. 
Jensen J.S., Wellendorf H., Jager K., De Vries S.M.G., and Jensen, V., 1997. Analysis of a 17-year old Dutch open-pollinated progeny trial with Quercus robur (L.). For. Genet. 4: 139-147.

Jensen J.S., 2000. Breeding of broadleaves in a Nordic perspective. Baltic Forestry 6: 67-77.

Jensen J.S and Hansen J.K., 2008. Geographical variation of phenology of Quercus petraea (Matt.) Liebl and Q. robur L. oak grown in a greenhouse. Scand. J. For. Res. 23:179-188.

Johnson H., 1952. Ungdomsutvecklingen hos stälkeg, druvek och rödek. Svenska Skogvårdsforeningens Tidsskrift 50: 168-192 (in Swedish).

Jump A. and Peñuelas J., 2006. Genetic effects of chronic habitat fragmentation in a wind-pollinated trees. Proceedings of the National Academy of Sciences of the United States of America. Proc. Natl. Acad. Sci. USA 103: 8096-8100.

Kalinowski S.T., 2005. HP-Rare: a computer program for performing rarefaction on measures of allelic diversity. Mol. Ecol. Notes 5: 187 189.

Kalinowski S.T., Taper M.L., and Marshall T.C., 2007. Revising how the computer program CERVUS accommodates genotyping error increases success in paternity assignment. Mol. Ecol.16: 1099-1006.

Kleinschmit J. and Kleinschmit J.G.R., 2000. Quercus robur-Quercus petraea: a critical review of the species concept. Glas. sumske Pokuse 37: 441-452.

Kremer A., Zanetto A., and Ducousso A., 1997. Multilocus and multitrait measures of differentiation for gene markers and phenotypic traits. Genetics. 145, 1229-1241.

Kremer A., Dupouey J.L., Deans J.D., Cottrell J., Csaikl U.M., Finkeldey R., Espinel S. Jensen J.S., Kleinschmit J., Van Dam B., Ducousso A., Forrest I., Lopez de Heredia U., Lowe A.J., Tutkova M., Munro R.C., Steinhoff S., and Badeau V., 2002. Morphological variation in mixed oak stands (Quercus robur and Quercus petraea) is stable across western European populations. Ann. For. Sci. 59: 777-787.

Lepais O., Léger V., and Gerber S., 2006. High throughput microsatellite genotyping in oak species. Silvae Genet. 55: 238-240.

Lexer C., Heinze B., Gerber S., Macalka-Kampfer S., Steinkellner H., Kremer A., and Glössl J., 2000. Microsatellite analysis of maternal half-sib families of Quercus robur, pedunculate oak. (II): Inferring the number of pollen donors from the offspring. Theor. Appl. Genet. 99: $185-191$.

Lowe A., Harris S., and Ashton P., 2004. Ecological Genetics Design, Analysis and Application, Blackwell Publishing, 326 p.

Manly B.F.J., 2006. Randomization, bootstrap and Monte Carlo methods in Biology, Chapman and Hall, London. 455p.

Marshall T.C., Slate J., Kruuk L.E.B., and Pemberton J.M., 1998 Statistical confidence for likelihood-based paternity inference in natural populations. Mol. Ecol. 7: 639-655.

Mariette S., Cottrell J., Csaikl U.M., Goikoechea P., König, A., Lowe A.J., Van Dam B., Barreneche T., Bodénès C., Streiff R., Burg K., Groppe K., Munro R.C., Tabbener H., and Kremer A., 2002. Comparison of levels of genetic diversity detected with AFLP and microsatellite markers within and among mixed $O$. petraea (Matt.) Liebl. and $Q$. robur L. stands. Silvae. Genet. 51: 72-79.

Muir G. and Schlötterer C., 2005. Evidence for shared ancestral polymorphism rather than recurrent gene flow at microsatellites loci differentiating two hybridizing oaks (Quercus spp.). Mol. Ecol. 14: 549-561.

Nixon K.C., 1993. Infrageneric classification of Quercus (Fagaceae) and typification of sectional names. Ann. Sci. For. 50 (Suppl.): 25s-34s.
Olrik D. and Kjær E.D., 2007. The reproductive success of a Q. petraea $\times$ Q. robur F1-hybrid in back-crossing situations. Ann. For. Sci. 64: $37-46$.

Parelle J., Brendel O., Jolivet Y., and Dreyer E., 2007. Intra- and interspecific diversity in the response to waterlogging of two cooccurring white oak species (Quercus robur and Quercus petraea). Tree Physiol. 27: 1027-1034.

Petit R.J., Bodénès C., Ducousso A., Roussel G., and Kremer A. 2003. Hybridization as a mechanism of invasion in oaks. New Phytol. 161: 151-164.

Pritchard J.K., Stephens M., and Donnelly P., 2000. Inference of population structure using multilocus genotype data. Genetics 155: 945-959

Raymond M. and Rousset F., 1995. GENEPOP (version 1.2): population genetics software for exact tests and ecumenicism. J. Hered. 86: 248249.

Robledo-Arnuncio J.J. and Gil L., 2005. Patterns of pollen dispersal in a small population of Pinus sylvestris L. revealed by total-exclusion paternity analysis. Heredity 94: 13-22.

Rushton B.S., 1978. Quercus robur L. and Quercus petraea (Matt.) Liebl.: a multivariate approach to the hybrid problem. 1. Data aquisition, analysis and interpretation. Watsonia 12: 81-101.

Scotti-Saintagne C., Mariette S., Porth I., Goicoechea P., Barraneche T., Bodénès C., Burg, K., and Kremer, A.G., 2004. Genome scanning for interspecific differentiation between two closely related oak species Quercus robur L. and Q. petraea (Matt.) Liebl. Genetics 168: 16151626

Sokal R.R. and Wartenberg D.E., 1983. A test of spatial autocorrelation analysis using an isolation-by-distance model. Genet. 105: 219-237.

Siegismund H.R. and Jensen J.S., 2001. Intrapopulation and interpopulation genetic variation of Quercus in Denmark. Scand. J. For. Res. 16: $103-116$.

Steinkellner H., Fluch S., Turetschek E., Lexer C., Streiff R., Kremer A., Burg K., and Glössl J., 1997. Identification and characterization of $(\mathrm{GA} / \mathrm{CT})_{\mathrm{n}_{-}}$microsatellite loci from Quercus petraea. Plant Mol. Ecol. 33: 1093-1096.

Steinhoff S., 1998. Kontrollierte Kreuzungen zwischen Stiel- und Traubeneiche: Ergebnisse und Folgerungen. Allg. Forst- und Jagdz. 169: $163-168$

Streiff R., Labbe T., Bacilieri R., Steinkellner H., Glössl J., and Kremer A., 1998. Within-population genetic structure in Quercus robur L. and Quercus petraea (Matt.) Liebl. assessed with isozymes and microsatellites. Mol. Ecol. 7: 317-328.

Streiff R., Ducousso A., Lexer C., Steinkellner H., Glössl J., and Kremer A., 1999. Pollen dispersal inferred from paternity analysis in a mixed stand of Ouercus robur L. and Quercus petraea (Matt.) Liebl. Mol. Ecol. 8: 831-841.

Valbuena-Carabana M., Gonzalez-Martinez S.C., Sork V.L., Collada C., Soto A., Goicoechea P.G., and Gil L., 2005. Gene flow and hybridisation in a mixed oak forest (Quercus pyrenaica Willd. and Quercus petraea (Matts.) Liebl.) in central Spain. Heredity 95: 457-465.

Weir B.S., 1990. Genetic Data Analysis. Sinauer Publ., Sunderland, MA, Sinauer Associates, $377 \mathrm{p}$.

Weir B.S. and Cockerham C.C., 1984. Estimating F-statistics for the analysis of population structure. Evolution 38: 1358-1370. 